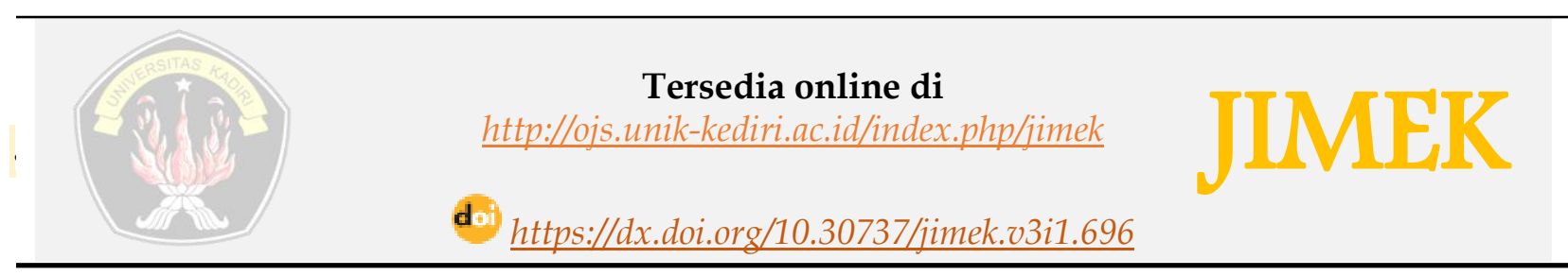

\title{
Analisis Capital Expenditure Dan Operating Cost Terhadap Keputusan Investasi
}

\author{
Rivaldi Muslim Ruswandi ${ }^{1}$, Dicky Jhoansyah ${ }^{2}$, Erry Sunarya ${ }^{3}$ \\ ${ }^{123}$ Fakultas Ilmu Administrasi dan Humaniora, Universitas Muhammadiyah Sukabumi \\ email: ${ }^{1}$ Rivaldimuslim040@ummi.ac.id, ${ }^{2}$ Dicky.jhoansyah@gmail.com, \\ ${ }^{3}$ Errysoen@gmail.com
}

\section{Artikel History: \\ Artikel masuk : 29-02-2020 \\ Artikel revisi : 13-03-2020 \\ Artikel diterima : 23-06-2020}

Keywords:

Capital expenditure, Operating

Cost, Keputusan Investasi

\begin{tabular}{l}
\hline ABSTRAK \\
\hline Tujuan dilakukannya penelitian ini ialah untuk mengetahui \\
pengaruh capital expenditure dan operating cost terhadap \\
keputusan investasi. Objek penelitian dalam penelitian ini ialah \\
3tahun laporan keuangan pada perusahaan-perusahaan makanan \\
dan minuman yang terdaftar di Bursa Efek Indonesia. Metode \\
penelitian yang digunakan dalam penelitian ini ialah dengan \\
metode kuantitatif pendekatan deskriptif dan asosiatif. Sampel \\
yang digunakan ialah dengan menggunakan pendekatan \\
Nonprobability Sampling dengan metode Purposive Sampling, \\
dari 18 perusahaan anggota subsektor makanan dan minuman \\
yang terdaftar di BEI terpilihlah 10 perusahaan menjadi sampel \\
penelitian. Teknik pengumpulan data ialah dengan menggunakan \\
data sekunder yaitu dengan dokumentasi dan studi kepustakaan. \\
Teknik analisa data yang digunakan dalam penelitian ini ialah \\
regresi linier berganda. Hasil dari penelitian ini menunjukan \\
adanya pengaruh secara positif dan signifikan dari capital \\
expenditure terhadap keputusan investasi, adanya pengaruh secara \\
negatif dari operating cost terhadap keputusan investasi namun \\
tidak signifikan. Dan adanya pengaruh secara bersama-sama dari \\
capital expenditure dan operating cost secara signifikan, dengan \\
tingkat pengaruh sebesar 20,2\%.
\end{tabular}

\section{ABSTRACT}

The purpose of this research is to find out the effect of capital expenditure and operating cost against invesment decision. The object in this research is 3 years annual statement food and beverage companies listed in Indonesia Stock Exchange. The research methods used quantitative methods with descriptive and associative approches. The sample used Nonprobability Sampling approach with Purposive Sampling method, from 18 food and beverage subsector companies listed on the Indonesia Stock Exchange, 10 companies were selected as research sample. The collecting data method is used secondary data with documentation and study of literature. The data analysis technique in this research used multiple linear regression. The results of this research indicate a positive and significant effect of capital expenditure on invesment decisions, indicate a negative and insignificant effect of operating cost on invesment decisions, and the simultaneous effect of capital expenditure and operating cost on invesment decisions significantly, with a level of effect $20,2 \%$. 


\section{PENDAHULUAN}

Iklim investasi di Indonesia pada saat ini sedang mengalami peningkatan dengan adanya penambahan penanaman modal. Terbukti menurut Badan Koordinasi Penanaman Modal (BKPM), pada kuartal II tahun 2019, terdapat sekitar 22.478 proyek baru dengan penanaman modal asing (PMA) US\$6.992,3 Juta dan dari penanam modal dalam negeri (PMDN) sekitar Rp.95.633,3 Miliar. Di Bursa Efek Indonesia sendiri, hingga kuartal 3 tahun 2019 terjadi penjualan saham sekitar 2.712.830 juta dengan nilai saham sekitar Rp.1.718.115 Miliar, itu berarti sekitar Rp.1.718 Triliun investasi masuk ke perusahaan-perusahaan yang ada di Bursa Efek Indonesia. Namun, meskipun penjualan saham meningkat sampai dengan kuartal III 2019, justru penurunan nilai saham jatuh dibanding tahun lalu yang mencapai nilai kumulatif Rp.2.040 Triliun. Menurut data laporan BEI, hampir semua sektor mengalami fluktuasi baik meningkat maupun menurun. Sektor barang konsumsi mengalami trend negatif atau paling menurun diantara sektor sektor lain, yaitu berdasarkan QoQ mengalami penurunan penjualan sekiat 11,98\% dan berdasarkan YTD turun sekitar 14,16\%.

Pada Subsektor Makanan dan Minuman, pada berita kontan.co.id dikemukakan bahwa kemenperin memproyeksikan sekitar pertumbuhan subsektor sekitar 9\%, yang mana ini berbanding terbalik dengan sektor barang konsumsi yang mengalami penurunan investasi, dimana subsektor makanan dan minuman merupakan bagian dari sektor barang konsumsi. Berikut disajikan grafik perolehan laba tiap perusahaan makanan dan minuman di Bursa Efek Indonesia,

Gambar 1. Data Perolehan Laba Perusahaan Subsektor Makanan dan Minuman

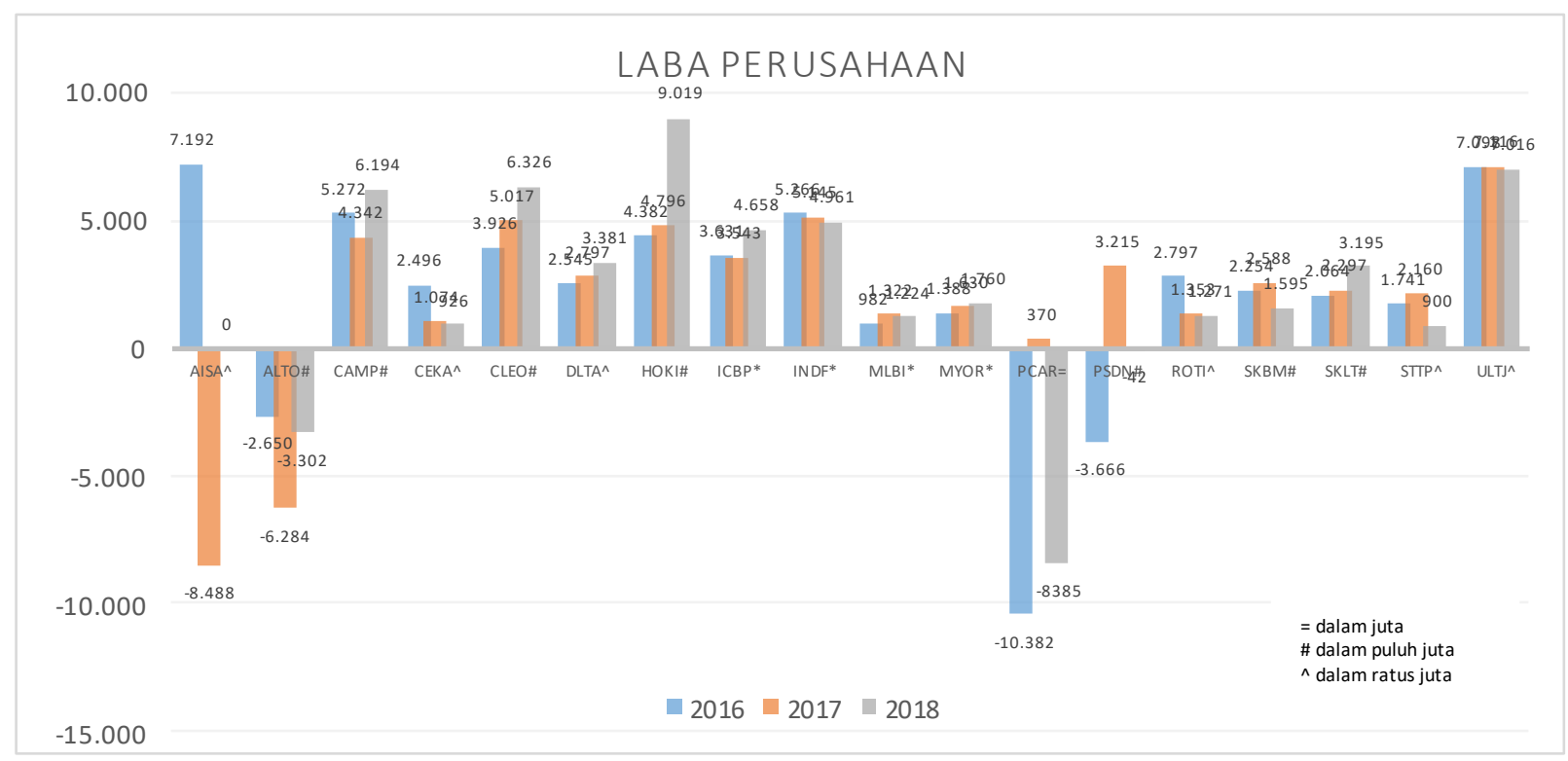

Sumber : Bursa Efek Indonesia, Data Diolah,2020 
Dari data grafik diatas, dilihat adanya fluktuasi laba tiap perusahaan, dimana naik turunnya laba perusahaan tersebut dipengaruhi oleh keputusan investasi perusahaan, sebab tingkat keberhasilan suatu manajemen keuangan dalam membuat keputusan investasi adalah kemampuan memilih aktiva nyata yang diambil alih yang mampu membawa tingkat pengembalian yang tinggi, dalam hal ini tingkat pengembalian tersebut ialah laba perusahaan. Pada penelitian Mutiara dan Kartawinata (2015), dilihat adanya pengaruh dari capital expenditure yang signifikan terhadap tingkat laba yaitu sebesar $86,5 \%$, pada penelitian Fitri (2014) bahwa capital expenditure mempunyai hubungan positif dengan pengembalian aset, lalu pada penelitian Liao et al. (2015) adanya pengaruh positif dari capital expenditure dan product market share. Pada penelitian Barus et al. (2016) menyatakan adanya pengaruh yang signifikan dari operating cost atau beban operasional yang signifikan terhadap laba bersih, dalam penelitian Marliana dan Fitri (2016) juga menyatakan bahwa biaya operasional berpengaruh terhadap pertumbuhan laba. Investasi yang dilakukan oleh perusahaan tak lepas dari dikeluarkannya pengeluaran modal yang besar untuk keberlangsungan produksi perusahaan, serta dilakukannya investasi juga diduga untuk menekan biaya operasional (operating cost) yang mana semakin besar volume produksi bisa jadi biaya operasi pun semakin tinggi.

Tujuan dari penelitian ini ialah untuk mengetahui faktor-faktor apa saja yang dapat mempengaruhi perusahaan melakukan investasi, diduga naik turunnya investasi yang dilakukan oleh perusahaan dikarenakan pengeluaran modal (capital expenditure) dan biaya operasional (operating cost).

\section{TINJAUAN PUSTAKA}

\section{Manajemen Keuangan}

Menurut Irham Fahmi (2018:2), Mengemukakan bahwa:

Manajemen Keuangan merupakan penggabungan dari ilmu dan seni yang membahas, mengkaji dan menganalisis tentang bagaimana seorang manajer keuangan dengan mempergunakan seluruh sumberdaya perusahaan untuk mencari dana, mengelola dana dan membagi dana dengan tujuan memberikan profit atau kemakmukan bagi para pemegang saham dan sustainability (keberlanjutan) usaha bagi perusahaan.

Menurut Horne dan Wachowicz Jr (dalam Maruta, 2018) manajemen keuangan mempunyai tiga fungsi, yaitu: 
R M Ruswandi, D Jhoansyah, E Sunarya / Jimek vol 3 no 1 tahun 2020

1. Keputusan investasi

Fungsi manajemen keuangan salah satunya ialah keputusan investasi, dimana keputusan investasi adalah hal yang penting dalam menunjang pengambilan keputusan dalam melakukan investasi, sebab mencakup tentang memperoleh dana investasi, dan mengenai mempertahankan atau mengurangi komposisi aset.

2. Keputusan Pendanaan

Fungsi manajemen keuangan sebagai keputusan pendanaan terkait tentang keputusan bagaimana laba yang didapat perusahaan ditahan untuk pembiayaan investasi dimasa yang akan datang atau dibagikan kepada para pemegang saham.

\section{Keputusan Manajemen Aset}

Fungsi manajemen keuangan yang ketiga ialah menyangkut tentang pengalokasian dana atau aset, dimana penggunaan sumber dana yang perlu dipertahankan dan penggunaan modal, baik berasal dari dari luar perusahaan maupun dari dalam perusahaan itu sendiri yang baik untuk perusahaan.

\section{Analisis Laporan Keuangan}

Laporan keuangan adalah salah satu kunci dimana perusahaan bisa terlihat dari setiap tahunnya dari keuangan yang diterbitkan oleh perusahaan merupakan salah satu sumber informasi yang sangat penting untuk mengenai posisi keuangan perusahaan, kinerja serta perubahan posisi keuangan perusahaan.(Sopian et al., 2019)

Analisis laporan keuangan menurut Munawir (2014:35), "Penelaahan atau mempelajari daripada hubungan-hubungan dan tendensi atau kecenderungan (trend) untuk menentukan posisi keuangan dan hasil operasi serta perkembangan perusahaan yang bersangkutan.”

Menurut Kasmir (2016:68) Analisis laporan keuangan dapat dipakai dua macam metode, ialah sebagai berikut:

\section{Analisis Vertikal}

Adalah analisis yang diproksikan untuk satu periode laporan keuangan. Analisis dilakukan terhadap bagian-bagian yang ada di satu periode laporan keuangan. Informasi yang didapat untuk satu periode laporang keuangan, sementara tidak diketahui periode-periode yang lain.

2. Analisis Horizontal

Analisis horizontal ialah analisis yang dikerjakan dengan membandingkan laporan dari beberapa periode. Dapat dilihat perkembangan perusahaan dari periode satu ke periode yang lain dengan digunakannya analisis horizontal. 


\section{Investasi}

Menurut Irham Fahmi (2015:6) investasi dapat didefinisikan sebagai "bentuk pengelolaan dana guna memberikan keuntungan dengan cara menempatkan dana tersebut pada alokasi yang diperkirakan akan memberikan tambahan keuntungan atau compounding".

Sedangkan menurut Tandelilin (dalam Lutfiana, et al., 2019) menyatakan bahwa "Investasi adalah komitmen atas sejumlah dana atau sumber daya lainnya yang dilakukan pada saat ini, dengan tujuan memperoleh sejumlah keuntungan di masa datang”.

\section{Capital Expenditure}

Pengertian Capital expenditure menurut Herry (2015:270),

"Capital Expenditure adalah biaya - biaya yang dikeluarkan dalam rangka memperoleh asset tetap, meningkatkan operasional dan kapasitas produktif asset tetap, serta memperpanjang masa manfaat asset tetap. Biaya - biaya ini biasanya di keluarkan dalam jumlah yang cukup besar(material), namun tidak sering terjadi."

Menurut Mulyadi (2010:16) “Capital Expenditure (Pengeluaran Modal) adalah biaya yang mempunyai manfaat lebih dari satu periode akuntansi (biasanya satu periode akuntansi adalah satu tahun kalender).”

\section{Operating Cost}

Menurut Werner Murhadi (2013:37) mengemukakan operating cost atau biaya operasional sebagai berikut:

Biaya operasi merupakan biaya yang terkait dengan operasional perusahaan yang meliput biaya penjualan dan administrasi (selling and administrative expense), biaya iklan (advertising expense), biaya penyusutan (depreciation and amortization expense), serta perbaikan dan pemeliharaan (repairs and maintenance expense).

Menurut Margaretha (2011:24) mengemukakan biaya operasional sebagai berikut: "Biaya Operasional adalah keseluruhan biaya sehubungan dengan operasional diluar kegiatan proses produksi termasuk didalamnya adalah (1) biaya penjualan dan (2) biaya administrasi dan umum".

\section{Keputusan Investasi}

Pengertian keputusan investasi menurut Sutrisno (2012:5): "keputusan investasi adalah masalah bagaimana manajer keuangan harus mengalokasikan dana kedalam bentuk-bentuk investasi yang akan dapat mendatangkan keuntungan dimasa yang akan datang.” 
"Keputusan investasi merupakan keputusan terhadap aktiva yang dikelola perusahaan. Investasi diartikan sebagai penanaman modal perusahaan. Penanaman modal dapat dilakukan pada aktiva rill ataupun aktiva finansial." (Sudiarto, 2016)

\section{Gambar 2. Paradigma Penelitian}

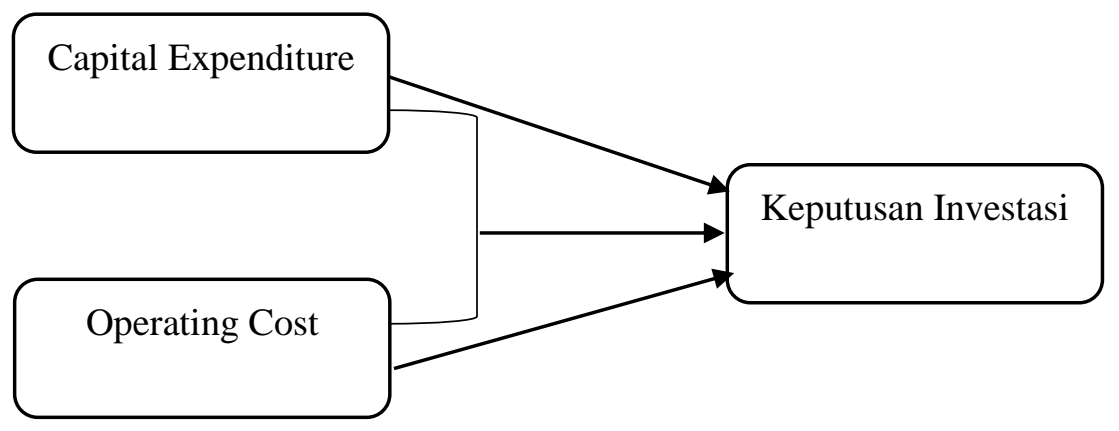

Dari paradigma diatas, hipotesis yang diasumsikan ialah sebagai berikut,

$\mathrm{H}_{1}$ Adanya pengaruh positif dan signifikan dari capital expenditure terhadap keputusan investasi

$\mathrm{H}_{2}$ Adanya pengaruh positif dan signifikan dari operating cost terhadap keputusan investasi

$\mathrm{H}_{3}$ Adanya pengaruh secara simultan dari capital expenditure dan operating cost terhadap keputusan investasi

\section{METODE PENELITIAN}

\section{Objek Penelitian}

Objek penelitian dalam penelitian ini ialah 3tahun laporan keuangan pada perusahaanperusahaan industri makanan dan minuman yang terdaftar di Bursa Efek Indonesia.

\section{Populasi dan Sampel}

Populasi dari penelitian ini ialah satu subsektor industri makanan dan minuman yang terdaftar di Bursa Efek Indonesia dengan anggota populasi sebanyak 18 perusahaan terdaftar.

Teknik pengambilan sampel dari penelitian ini ialah dengan menggunakan pendekatan nonprobability sampling dengan metode purposive sampling, sehingga dari 18 perusahaan anggota populasi terpilih 10 perusahaan untuk menjadi sampel penelitian.

\section{Teknik Pengumpulan Data}

Pada penelitian ini menggunakan teknik pengumpulan data sekunder, yaitu dengan dokumentasi dan studi kepustakaan. Dokumentasi disini ialah pengumpulan data berupa dokumen-dokumen berupa laporan keuangan perusahaan terkait yang bersumber dari Bursa Efek Indonesia, sedangkan studi kepustakaan disini ialah untuk menghimpun teori-teori dan 
kajian-kajian baik berupa buku, jurnal, artikel website, dll, yang dapat mendukung penelitian ini.

\section{Operasional Konsep}

Berikut disajikan operasional konsep dari penelitian ini sebagai berikut,

Tabel 1. Operasional Konsep

\begin{tabular}{|c|c|c|c|}
\hline Variabel & Pengertian & Indikator & Konsep \\
\hline $\begin{array}{l}\text { Capital } \\
\text { Expenditure }\end{array}$ & $\begin{array}{l}\text { Capital Expenditure adalah biaya } \\
\text { - biaya yang dikeluarkan dalam } \\
\text { rangka memperoleh asset tetap, } \\
\text { meningkatkan oprasional dan } \\
\text { kapasitas produktif asset tetap, } \\
\text { serta memperpanjang masa } \\
\text { manfaat asset tetap. Biaya - biaya } \\
\text { ini biasanya di keluarkan dalam } \\
\text { jumlah yang cukup } \\
\text { besar(material), namun tidak } \\
\text { sering terjadi }\end{array}$ & $\begin{array}{l}\text { - Aktiva } \\
\text { Tetap } \\
- \\
\text { Depresiasi } \\
\text { Aktiva } \\
\text { Tetap }\end{array}$ & $\begin{array}{l}\text { Lukman Syamsudin (dalam Mutiara } \\
\& \text { Kartawinata, 2015) yaitu: } \\
\Delta F A_{t}=N F A_{t}+D e p_{t}-N F A_{t-1}\end{array}$ \\
\hline $\begin{array}{l}\text { Operating } \\
\text { Cost }\end{array}$ & $\begin{array}{l}\text { Biaya operasi merupakan biaya } \\
\text { yang terkait dengan operasional } \\
\text { perusahaan yang meliputi biaya } \\
\text { penjualan dan administrasi } \\
\text { (selling and administrative } \\
\text { expense), biaya iklan (advertising } \\
\text { expense), biaya penyusutan } \\
\text { (depreciation and amortization } \\
\text { expense), serta perbaikan dan } \\
\text { pemeliharaan }\end{array}$ & $\begin{array}{l}\text { - Biaya } \\
\text { Penjuala } \\
\mathrm{n} \\
\text { - Biaya } \\
\text { Administ } \\
\text { rasi dan } \\
\text { Umum }\end{array}$ & $\begin{array}{l}\text { Rudianto (dalam Salamah, et al., } \\
\text { 2016), } \\
\text { Biaya operasional = } \\
\text { Biaya penjualan + biaya administrasi } \\
\text { dan umum }\end{array}$ \\
\hline $\begin{array}{l}\text { Keputusan } \\
\text { Investasi }\end{array}$ & $\begin{array}{l}\text { Merupakan ukuran keberhasilan } \\
\text { perusahaan atas operasi di masa } \\
\text { lalu dan prospek dimasa datang } \\
\text { yang diukur dengan adanya } \\
\text { perubahan aset tetap }\end{array}$ & $\begin{array}{l}\text { - Aset } \\
\text { Tetap }\end{array}$ & $\begin{array}{l}\text { Case dan Fair (dalam Rolita, 2014) } \\
\qquad \Delta A T=\frac{\text { Aset Tetap } Y_{2}-\text { Aset Tetap } Y_{1}}{\left(\text { Aset Tetap } Y_{2}+\text { Aset Tetap } Y_{1}\right) / 2} \times 100 \%\end{array}$ \\
\hline
\end{tabular}

\section{Teknik Analisa Data}

\section{Uji Normalitas}

Uji normalitas bertujuan untuk menguji apakah dalam model regresi, variabel pengganggu atau residual memiliki distribusi normal atau tidak. Jika uji asumsi ini dilanggar maka uji statistik tidak valid untuk jumlah sampel kecil (Anam \& Zuardi, 2018).

Menurut Ghozali (dalam Efilia, 2014), uji statistik yang dapat digunakan untuk menguji normalitas residual adalah uji statistik non parametrik Kolmogorov- Smirnov (K-S).

Uji K-S dilakukan dengan hipotesis :

$\mathrm{HO}=$ data residual berdistribusi normal

$\mathrm{HA}=$ data residual tidak berdistribusi normal

Apabila nilai sig. > 0,05 maka H0 diterima dan HA ditolak, sebaliknya jika nilai sig. < 0,05 maka H0 ditolak dan HA diterima. 


\section{Koefisien Determinasi}

Koefisien determinasi berganda $\left(\mathrm{R}^{2}\right)$ adalah estimasi proporsi variabel terikat keputusan investasi (Y), yang disumbangkan oleh variabel bebas, yaitu variabel capital expenditure (X1) dan operating cost (X2).

Koefisien determinasi (KD) dihitung dengan rumus sebagai berikut (Hidayat, 2019):

$$
K d=r^{2} X 100 \%
$$

$$
\begin{aligned}
& \mathrm{Kd}=\text { Koefisien Determinasi } \\
& \mathrm{r}^{2}=\text { Koefisien Korelasi }
\end{aligned}
$$

Kriteria untuk koefisien determinasi :

1. Jika "KD" mendekati 0 maka pengaruh variabel $\mathrm{X}$ terhadap $\mathrm{Y}$ lemah

2. Jika "KD" mendekati 1 maka pengaruh variabel X terhadap Y kuat

\section{Uji Regresi Linier Berganda}

Sugiyono (2017:188) menyatakan bahwa "Analisis regresi ganda digunakan oleh penulis, untuk meramalkan bagaimana keadaan (naik turunnya) variabel dependen, bila dua variabel independen sebagai faktor prediktor dimanipulasi (dinaik turunkan nilainya)".

Dengan rumus sebagai berikut:

$$
\mathrm{Y}^{*}=\mathrm{a}+\mathrm{b}_{1} \mathrm{X}_{1}+\mathrm{b}_{2} \mathrm{X}_{2}
$$

Keterangan:

$\mathrm{Y}^{*} \quad=$ Subyek dalam dependent variable yang diprediksikan

$\mathrm{X} \quad=$ independent variable

a $\quad=$ Harga $Y$ ketika $X=0$ (harga konstan)

$\mathrm{b} \quad=$ Angka atau koefisien regresi yang menunjukan angka peningkatan ataupun penurunan dependent variable yang disebabkan pada perubahan independent variable

\section{Uji Hipotesis}

\section{Uji t (parsial)}

Menurut Sugiyono (dalam Hidayat, 2019) rumus hitung $t$ test ialah sebagai berikut:

$$
t=\frac{\mathrm{r} \sqrt{n-2}}{\sqrt{1}-r^{2}}
$$


Keterangan :

t : Nilai Uji t

r : Koefisien Korelasi Pearson

$\mathrm{r}^{2}:$ Koefisien Determinasi

n : Jumlah Sampel

Hasil perhitungan ini selanjutnya dibandingkan dengan t tabel dengan menggunakan tingkat kesalahan 0,05 uji dua pihak dan $\mathrm{dk}=\mathrm{n}-2$, kriteria sebagai berikut :

Jika signifikansi $\mathrm{t} \leq 0,05$ dan jika $\mathrm{t}>0$, maka $\mathrm{H}_{0}$ ditolak dan $\mathrm{H}_{1}$ diterima Jika signifikansi $\mathrm{t} \geq 0,05$ dan jika $\mathrm{t}<0$, maka $\mathrm{H}_{\mathrm{o}}$ diterima dan $\mathrm{H}_{1}$ ditolak

\section{Uji f (simultan)}

Koefisien korelasi ganda dapat diuji menggunakan rumus uji F, menurut Sugiyono (dalam Hidayat, 2019) ialah sebagai berikut:

$$
F_{h}=\frac{R^{2} / k}{\left(1-R^{2}\right) /(n-k-1)}
$$

Keterangan :

R : Nilai koefisien korelasi ganda

$\mathrm{k} \quad$ : Jumlah variabel bebas (independent)

n : Jumlah sampel

F : F hitung selanjutnya akan dibandingkan dengan F sampel

Uji hipotesis korelasi ganda langsung dikonsultasikan dengan harga $\mathrm{F}$ tabel dengan didasarkan pada DK pembilang $-\mathrm{k}$ dan DK penyebut $=(\mathrm{n}-\mathrm{k}-1)$ dan taraf kesalahan yang ditetapkan adalah 0,05 kaidah pengujian signifikansi yaitu sebagai berikut :

1. Jika $F_{\text {hitung }} \geq F_{\text {tabel }}$ maka signifikan

2. Jika $F_{\text {hitung }} \leq \mathrm{F}_{\text {tabel }}$ maka tidak signifikan.

\section{HASIL \& PEMBAHASAN}

1. Perhitungan capital expenditure

Berdasarkan operasional konsep diatas didapat hasil sebagai berikut,

ALTO, 2016

$\Delta F A_{t}=N F A_{t}+D e p_{t}-N F A_{t-1}$

$\Delta F A_{t}=605.273+168.745-583.093$

$\Delta F A_{t}=190.925$ 
R M Ruswandi, D Jhoansyah, E Sunarya / Jimek vol 3 no 1 tahun 2020

Jadi, pada tahun 2016, ALTO mengeluarkan capital expenditure dengan menggunakan $\Delta \mathrm{FA}_{\mathrm{t}}$ adalah sebesar 190.925 .

2. Perhitungan Operating Cost

ALTO, 2016

Biaya operasional $=$ Biaya penjualan + Biaya administrasi dan umum

Biaya Operasional $=24.728+35.235$

Biaya Operasional $=59.963$

Jadi pada tahun 2016, ALTO mengeluarkan biaya operasional sebesar Rp. 59.963.

3. Keputusan Investasi

ALTO, 2016

$\Delta \mathrm{AT}=\frac{\text { Aset Tetap } Y_{2}-\text { Aset Tetap } Y_{1}}{\left(\text { Aset Tetap } Y_{2}+\text { Aset Tetap } Y_{1}\right) / 2} \times 100 \%$

$\Delta \mathrm{AT}=\frac{605.273-583.093}{(602.273+583.093) / 2} \times 100 \%$

$\Delta \mathrm{AT}=\frac{22.179}{594.183} \times 100 \%$

$\Delta \mathrm{AT}=0,0373 \times 100 \%$

$\Delta \mathrm{AT}=3,73 \%$

Jadi pada tahun 2016, ALTO membuat keputusan investasi berdasarkan $\Delta \mathrm{AT}$ sebesar $3,73 \%$

Berdasarkan perhitungan capital expenditure, operating cost dan keputusan investasi perusahaan-perusahaan subsektor industri makanan dan minuman, didapatlah hasil sebagai berikut,

Tabel 2. Hasil Perhitungan Capex, Operating Cost, dan Keputusan Investasi perusahaan subsektor makanan dan minuman

\begin{tabular}{ccccc}
\hline Perusahaan & Tahun & CAPEX & Operating Cost '000 & Kep.Investasi \\
\hline ALTO & & (Rp. '000.000) & (Rp. '000.000) & (\%) \\
\hline & 2016 & 190.925 & 59,963 & 3.73 \\
\hline & 2017 & 287,848 & 75,168 & 38.42 \\
\hline DLTA & 2018 & $-9,917$ & 51,717 & -1.11 \\
\hline & 2016 & $-9,038$ & 246,863 & -8.96 \\
\hline & 2017 & $-6,296$ & 242,666 & -6.76 \\
\hline ICBP & 2018 & 212 & 254,692 & 0.23 \\
\hline & 2016 & 558,628 & $5,923,159$ & 8.17 \\
\hline INDF & 2017 & $1,005,966$ & $5,681,180$ & 13.20 \\
\hline & 2018 & $2,621,368$ & $6,493,793$ & 27.79 \\
\hline & 2017 & 605,571 & $11,156,937$ & 2.38 \\
\hline & 2018 & $2,790,374$ & $11,307,271$ & 43.68 \\
\hline
\end{tabular}




\begin{tabular}{ccccc} 
MLBI & 2016 & 11,943 & 775,212 & 0.93 \\
\hline & 2017 & 68,071 & 700,593 & 5.18 \\
\hline MYOR & 2018 & 177,975 & 809,465 & 12.40 \\
\hline & 2016 & 88,724 & $2,585,180$ & 2.32 \\
\hline & 2017 & 129,337 & $2,514,495$ & 3.28 \\
\hline ROTI & 2018 & 269,543 & $3,768,761$ & 6.53 \\
\hline & 2016 & 21,344 & 916,136 & 1.16 \\
\hline & 2017 & 150,940 & $1,106,974$ & 7.68 \\
\hline SKBM & 2018 & 228,469 & $1,353,753$ & 10.83 \\
\hline & 2016 & 42,687 & 128,067 & 10.29 \\
\hline & 2017 & 49,539 & 156,734 & 10.74 \\
\hline SKLT & 2018 & 97,091 & 180,962 & 18.17 \\
\hline & 2016 & 151,117 & 180,911 & 67.42 \\
\hline & 2017 & 12,135 & 195,710 & 3.96 \\
\hline ULTJ & 2018 & 11,434 & 213,149 & 3.60 \\
\hline & 2016 & $-118,640$ & 771,136 & -5.38 \\
\hline & 2017 & 294,323 & 861,851 & 24.74 \\
\hline
\end{tabular}

Sumber : Data diolah peneliti, 2020

\section{Uji Normalitas}

Tabel 3. Uji Normalitas

One-Sample Kolmogorov-Smirnov Test

\begin{tabular}{llr} 
& & \multicolumn{1}{c}{$\begin{array}{c}\text { Unstandardized } \\
\text { Residual }\end{array}$} \\
\hline N & Mean & 30 \\
\cline { 2 - 3 } & Std. Deviation & .0000000 \\
\hline Most Extreme Differences & Absolute & 1.41645992 \\
\cline { 2 - 3 } & Positive & .161 \\
\cline { 2 - 3 } & Negative &. .161 \\
\hline Test Statistic & & .161 \\
\hline Asymp. Sig. (2-tailed) & & $.143^{c}$ \\
\hline
\end{tabular}

a. Test distribution is Normal.

b. Calculated from data.

c. Lilliefors Significance Correction.

Sumber : Data diolah, 2020

Dari data diatas dapat diketahui nilai Kolmogorov-Smirnov Z sebesar 0,161 dengan nilai signifikansinya (Asymp. Sig (2-tailed) sebesar 0,143>0,05) yang berarti data residual berdistribusi normal dan Ho diterima.

\section{Regresi Linier Berganda}


R M Ruswandi, D Jhoansyah, E Sunarya / Jimek vol 3 no 1 tahun 2020

Tabel 4. Regresi Linier Berganda

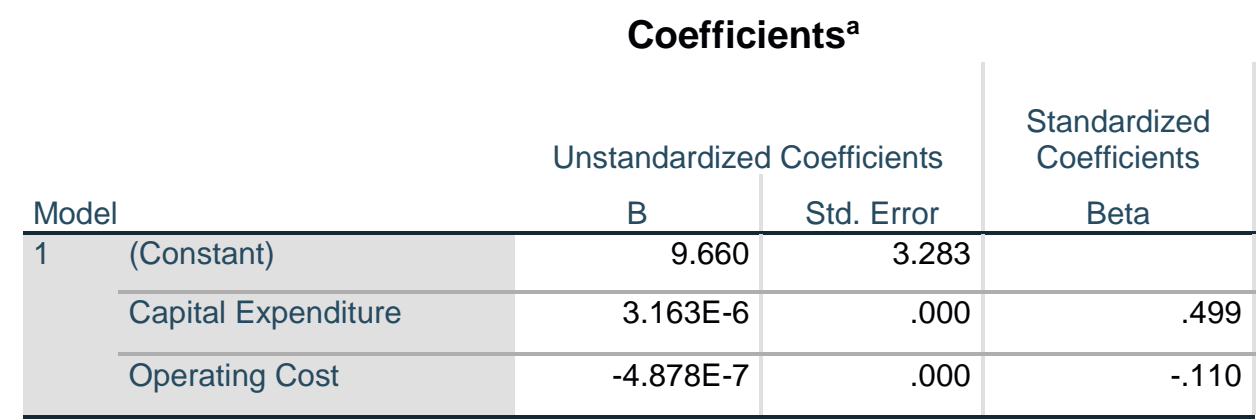

a. Dependent Variable: keputusan Investasi

Sumber : Data Diolah, 2020

Berdasarkan hasil perhitungan regresi, maka diperoleh nilai $b_{1}=3,163$ dan $b_{2}=-4,878$ sedangkan nilai $a=9,660$. Kemudian nilai tersebut dimasukkan kedalam persamaan regresi linier berganda sebagai berikut

$$
\begin{gathered}
Y=a+b_{1} X_{1}+b_{2} X_{2} \\
Y=9,660+3,163 X_{1}-4,878 X_{2}
\end{gathered}
$$

Arti persamaan tersebut adalah :

1. Nilai konstanta sebesar a $=9,660$ menyatakan bahwa jika capital expenditure dan operating cost tidak ada perubahan atau nilainya nol maka nilai variabel keputusan investasi adalah sebesar 9,660

2. Koefisien regresi capital expenditure sebesar $b_{1}=3.163$ menyatakan hubungan searah, artinya setiap peningkatan capital expenditure sebesar satu satuan maka hal tersebut akan meningkatkan keputusan investasi sebesar 3,163.

3. Koefisien regresi operating cost sebesar $\mathrm{b}_{2}=-4.878$, menunjukan indikasi adanya hubungan tidak searah. Artinya jika variabel operating cost mengalami peningkatan satu satuan, maka akan membuat penurunan keputusan investasi sebesar $-4,878$.

\section{Koefisien Determinasi}

\begin{tabular}{|c|c|c|c|c|c|}
\hline \multicolumn{6}{|c|}{ Model Summary } \\
\hline Model & $\mathrm{R}$ & R Square & $\begin{array}{l}\text { Adjusted R } \\
\text { Square } \\
\end{array}$ & $\begin{array}{c}\text { Std. Error of the } \\
\text { Estimate }\end{array}$ & Durbin-Watson \\
\hline 1 & $.449^{a}$ & .202 & .143 & 14.82243 & 1.894 \\
\hline
\end{tabular}

Tabel 5. Hasil Perhitungan Koefisien Determinasi

a. Predictors: (Constant), Operating Cost, Capital Expenditure

b. Dependent Variable: keputusan Investasi

Sumber : Data diolah,2020

Dari data tabel olahan diatas diperoleh angka $\mathrm{R}^{2}$ sebesar 0,202 atau 20,2\%. Nilai tersebut memberi pengertian bahwa capital expenditure (X1) dan operating cost (X2) memberikan sumbangan pengaruh sebesar 0,202 terhadap keputusan investasi. sedangkan sisanya sebesar 79,8\% dipengaruhi oleh variabel lain yang tidak diteliti dalam penelitian ini. 


\section{Uji Hipotesis}

\section{Uji t statisitk (parsial)}

Tabel 6. Hasil Perhitungan Uji t

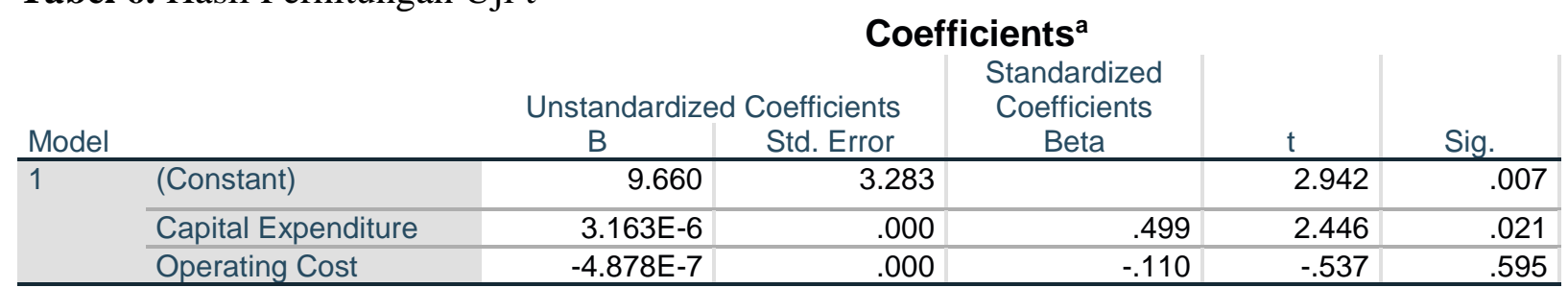

Sumber : Data diolah, 2020

Berdasarkan hasil uji t diatas maka diperoleh hasil sebagai berikut :

1. Pengujian Capital Expenditure (X1)

Dari data tabel diatas menunjukan capital expenditure memiliki nilai t hitung $>\mathrm{t}$ tabel $(2,446>2,051)$ dan signifikansi $(0,021<0,05)$ artinya secara parsial ada pengaruh signifikan capital expenditure terhadap keputusan investasi.

2. Pengujian Operating Cost (X2)

Dari data tabel diatas menunjukan operating cost memiliki nilai -t hitung > -t tabel ($0,537>-2,051)$ dan signifikansi $(0,595>0,05)$ artinya secara parsial ada pengaruh dari operating cost terhadap keputusan investasi, namun tidak signifikan.

\section{Uji f test (simultan)}

Tabel 7. Hasil Perhitungan Uji f

\begin{tabular}{ll|r|r|r|r|r}
\multicolumn{7}{c}{ ANOVA $^{\text {a }}$} \\
Model & & Sum of Squares & df & Mean Square & F & Sig. \\
\hline 1 & Regression & 1501.957 & 2 & 750.979 & 3.418 & $.048^{\mathrm{b}}$ \\
\cline { 2 - 7 } & Residual & 5932.017 & 27 & 219.704 & & \\
\cline { 2 - 7 } & Total & 7433.974 & 29 & & \\
\hline
\end{tabular}

a. Dependent Variable: keputusan Investasi

b. Predictors: (Constant), Operating Cost, Capital Expenditure

Sumber : Data diolah, 2020

Dari tabel diatas dapat diketahui bahwa nilai Fhitung > Ftabel $(3,42>3,35)$ dan signifikansi $(0,048<0,05)$, artinya ada pengaruh secara bersama-sama dari capital expenditure dan operating cost terhadap keputusan investasi secara signifikan.

\section{SIMPULAN \& SARAN}

Dari hasil dan pembahasan diatas, peneliti dapat menyimpulkan sebagai berikut :

1. Adanya pengaruh dari capital expenditure secara positif dan signifikan terhadap keputusan investasi pada perusahaan subsektor makanan dan minuman yang terdaftar di Bursa Efek Indonesia 
R M Ruswandi, D Jhoansyah, E Sunarya / Jimek vol 3 no 1 tahun 2020

2. Adanya pengaruh dari operating cost secara negatif dan tidak signifikan terhadap keputusan investasi pada perushaan subsektor makanan dan minuman yang terdaftar di Bursa Efek Indonesia

3. Adanya pengaruh secara bersama-sama dari capital expenditure dan operating cost secara signifikan terhadap keputusan investasi pada perusahaan subsektor makanan dan minuman yang terdaftar di Bursa Efek Indonesia dengan estimasi proporsi pengaruh sebesar $20,2 \%$.

\section{DAFTAR PUSTAKA}

Anam, C., \& Zuardi, L. R. (2018). Analisis Rasio Likuiditas, Rasio Solvabilitas, Dan Biaya Operasional Terhadap Pajak Penghasilan Badan Terutang. MARGIN ECO, 2(1), 43-68.

Bursa Efek Indonesia. (2019). IDX Quarterly Statistics.

Efilia, M. (2014). PENGARUH PENDAPATAN USAHA DAN BEBAN OPERASIONAL TERHADAP LABA BERSIH PADA PERUSAHAAN KIMIA DAN KERAMIK,PORSELIN \& KACA YANG TERDAFTAR DI BURSA EFEK INDONESIA PERIODE 2008-2012. E- Journal. Fakultas Ekonomi. Universitas Maritim Raja Ali Haji Tanjungpinang, 1-15.

Fahmi, I. (2015). Pengantar Teori Portofolio dan Analisis Investasi (1st ed.). Bandung: Alfabeta.

Fahmi, I. (2018). Pengantar Manajemen Keuangan Teori dan Soal Jawab (6th ed.; M. A. Djalil, Ed.). Bandung: Alfabeta.

Fitri, I. N. (2014). Analisis Pengaruh Tingkat Kenaikan Penggunaan Capital Expenditure Terhadap Kinerja Perusahaan (Studi Empiris Pada Perusahaan Manufaktur Yang Terdaftar Di Bursa Efek Indonesia). Jurnal Unesa, 1-19.

Hery. (2015). Analisis Laporan Keuangan. Yogyakarta: Center for Academic Publishing Service.

Hidayat, W. A. (2019). Analisis Invesment Opportunity Set (IOS) dan Profitabilitas terhadap Kebijakan Dividend. Universitas Muhammadiyah Sukabumi.

Kasmir. (2016). Analisis Laporan Keuangan (11th ed.). Jakarta: RajaGrafindo Persada.

Liao, L., Lin, Y., \& Lin, T. (2015). Non- fi nancial performance in product market and capital expenditure Journal of Business Research. https://doi.org/10.1016/j.jbusres.2015.12.023

Lutfiana, A., Danial, R. D. M., \& Jhoansyah, D. (2019). ANALISIS PENILAIAN HARGA WAJAR SAHAM DAN KEPUTUSAN INVESTASI SECARA FUNDAMENTAL DENGAN MENGGUNAKAN Metode PRICE EARNING RATIO. Ekobis, 20(2), 1-10.

Margaretha, F. (2011). Manajemen Keuangan untuk Manajer Non Keuangan. Jakarta: Salemba Empat.

Maruta, H. (2018). Analisis Laporan Keuangan Model Du Pont Sebagai Analisis Yang Integratif. 203-227.

Mulyadi. (2010). Sistem Akuntansi (3rd ed.). Jakarta: Salemba Empat.

Munawir. (2014). Analisis Laporan Keuangan. Yogyakarta: Liberty.

Murhadi, W. R. (2013). Analisis Laporan Keuangan Proyeksi dan Valuasi Saham. Jakarta: Salemba Empat.

Mutiara, N. A., \& Kartawinata, B. R. (2015). Pengaruh Capital Expenditure Terhadap Tingkat Laba ( Pada Perusahaan Jasa Telekomunikasi Yang Terdaftar Di Bursa Efek Indonesia Periode 2009-2013 ). Jurnal FKB, (2013), 1-9. 
Rolita, R. (2014). Hubungan Struktur Modal dan Keputusan Investasi pada Perusahaan Manufaktur. Jurnal Keuangan Dan Perbankan, 18(3), 370-383.

Salamah, A. A., Pamungkas, M. G. W. E. N., \& Yogi, K. (2016). Pengaruh Profitabilitas Dan Biaya Operasional Terhadap Pajak Penghasilan Badan (Studi Pada Perusahaan Manufaktur Yang Terdaftar Di Bursa Efek Indonesia Periode 2012-2014). Jurnal Perpajakan (JEJAK), 9(1), 35-40. https://doi.org/10.1109/ciced.2018.8592188

Sopian, M. I., Sunarya, E., \& Komariah, K. (2019). ANALISIS KEMAMPUAN RASIO LIKUIDITAS DAN PROFITABILITAS DALAM MENGUKUR FINANCIAL DISTRESS. COSTING:Journal of Economic, Business and Accounting, 3(1), 145-152.

Sudiarto, R. E. (2016). Pengaruh keputusan investasi, keputusan pendanaan, kebijakan deviden dan tingkat suku bunga terhadap nilai perusahaan. Universitas Muhammadiyah Surakarta.

Sugiyono. (2017). Metode Penelitian Kuantitatif, Kualitatif, Dan R\&D. Bandung: Alfabeta.

Sutrisno. (2012). Manajemen Keuangan Teori Konsep dan Aplikasi. Yogyakarta: Ekonisia.

TA, C. M., \& Fitri, M. (2016). PENGARUH BIAYA OPERASIONAL , DANA PIHAK KETIGA DAN NON PERFORMING FINANCE TERHADAP PERTUMBUHAN LABA PADA PERBANKAN SYARIAH DI INDONESIA. Jurnal Ilmiah Mahasiswa Ekonomi Akuntansi (JIMEKA), 1(1). 